\title{
The Research of the Effect of Computer and Information Literacy Self-Efficacy on the Achievement of Information Literacy
}

\author{
Murat TUNCER (Corresponding author)
}

Dept. of Educational Sciences, Firat University

23119, Elazig TURKEY

Tel: 90-424-237-0000Ｅ-mail: mtuncer@firat.edu.tr

\author{
Kürşat BALCI \\ Institude of Educational Sciences, Firat University \\ 23119, ELAZIĞ TURKEY \\ E-mail: evc.988@gmail.com
}

Received: Sep. 2, 2013 Accepted: September 25, 2013 Published: November 1, 2013

doi:10.5296/jse.v3i4.4212 URL: http://dx.doi.org/10.5296/jse.v3i4.4212

\begin{abstract}
In this research, the relations between the information literacy self-efficacy and computer self-efficacy as well as the achievement of information literacy are examined. The scale of information literacy self-efficacy, computer self-efficacy and information literacy achievement test are applied to 783 teacher candidates receiving education at Faculty of Education in Firat University. It is determined with the regression analysis how the achievement of information literacy self-efficacy, computer self-efficacy and information literacy affect each other; when the regression (beta) coefficients standardized as a result of the analysis are examined, it is observed that the computer self-efficacy has a positive effect on information literacy self-efficacy. Nonetheless, it is observed that the information literacy self-efficacy has no significant effect on the achievement of information literacy, and also the computer self-efficacy has no significant effect on the achievement of information literacy.
\end{abstract}

Keywords: Information literacy self-efficacy, Computer self-efficacy, The achievement of information literacy, Teacher training, Regression analysis 


\section{Introduction}

This research includes a multi-perspective view. Effort is made to explain the information literacy and computer skills self-efficacy considered among the life-long learning skills in an individual dimension. Initially, effort is made to explain the concept of self-efficacy, the information literacy, computer self-efficacy and the achievement of information literacy are discussed on a relational level.

\section{Self-Efficacy}

Self-efficacy is one of the significant variables used to explain affective aspect of the teacher in the recent years. It is believed that the perception of self-efficacy is an efficient state in learning. After the student-oriented learning approaches are widely accepted, the self-efficacy is important in terms of defining the learning with regards to individual (Tuncer \& Tanaş, 2011).

According to the Bandura, the self-efficacy is the judgment of individuals about themselves for the capacity of successfully organizing and realizing the activities required for a certain performance (Lee, 2005; Cit. Acar, 2007). When the researches on the self-efficacy are examined, it is in evidence that the self-efficacy is not a observable skill (Snyder \& Lopez, 2002), it cannot be defined as a skill (Donald, 2003: Cit. Acar, 2007). Nevertheless, the self-efficacy has effects on the cognitive, behavioral, affective and choosing processes (Bandura, 1994). These effects can be summarized as: According to Pajares (1997), the perception of efficacy affects the choices, course and behavioral patterns of the individuals. Most people take on the tasks that they feel sufficient and safe. Otherwise, they avoid the tasks. The experiences have key role in the jobs people chose and defining the self-belief affecting the people's choices. According to Bandura (2001), the efficacy belief affects motivation through the effect on objectives. Which difficulties to be taken on, the degree of the effort and the resistance against the difficulties performed by the individuals are based partly on efficacy beliefs. When faced with the obstacles, difficulties and failures, the individuals distrusting their skills either reduce their efforts or quit. The others increase their effort to overcome these tasks.

\section{Information Literacy and Self-Efficacy}

The concept of information literacy was brought to the agenda with a report foreseeing integration in the national education program in USA at the beginning of 1970s (Polat, 2006). According to the definition by American Library Association (ALA) in 1989, the information literacy was defined as "to feel the need of information, to find the information needed, to evaluate the information obtained and to use the information in an efficient manner." (Kurbanoğlu, 2010). According to Polat (2005) quoting from Houff (2002), the changes have expanded the aspect of literacy. Therefore, the literate were considered as not just reading and writing the information in the resources, but also interpreting and applying this information. Especially in the definitions made in 2000s, it draws the attention that the information literacy is related with all the fields of life and other literacy skills and its benefits are featured (Kurbanoğlu, 2010). Bundy (2004) states that the information literacy is a prerequisite for 
participatory citizenship, social acceptance, new information production, personal and corporate development and lifelong learning. As the information literacy skills are among the main educational goals, the standards related to information literacy skills are developed in many countries, especially USA.

The perception of self-efficacy applies to information literacy as well as all the fields. The information literacy self-efficacy belief can be defined as "the belief of the individuals towards reaching the information, using the information, sharing the information and evaluating the information." (Akkoyunlu \& Kurbanoğlu, 2004). The individuals have to develop a positive perception of self-efficacy in terms of information skills in order to apply the information problem solving activities successfully and to be self-leading, self-motivating and lifelong learner (Akkoyunlu \& Kurbaoğlu, 2003).

\section{Computer Self-Efficacy}

It is observed that the self-efficacy, a concept developed in the field of social psychology, is adapted to many fields. The perception of computer self-efficacy defined as "the judgment of individual about computer skills" by Compeau and Higgins (1995) is one of the adaptations of self-efficacy. The studies conducted about the perception of computer self-efficacy show that the individuals having higher perception of computer self-efficacy are more eager to participate in the activities related to computers and have higher expectations in this kind of activities. Besides, when these individuals experience any difficulties about computer, they can overcome these difficulties easily (Karsten\&Roth 1998; Compeau \& Higgins 1995). The international studies conducted in this field show that the perception of self-efficacy is a universal structure (Schwarzer, Bässler, Kwiatek and Schröder, 1997). Albion (1999) states that the perception of computer self-efficacy is a significant structure affecting computer usage of teachers and students in the classroom.

It can be generalized that the perceptions of individuals in terms of both computer literacy and information literacy can increase their achievement. In another words, the high perception of self-efficacy encourages to try and experience some things. This situation is one of the conditions for self-learning and self-motivation (Akkoyunlu \& Kurbanoğlu, 2003). McClure (1994) explains information literacy as the combination of visual literacy, network, media literacy and computer literacy. A similar definition is made by Kurbanoğlu(2010), and computer literacy is considered as a part of, even a prerequisite for information literacy. This relationship between information literacy and computer literacy is also shown in the study by Akkoyunlu and Kurbanoğlu'nun (2003). Similar results are further encountered in the studies by Korkut and Akkoyunlu (2008), Kaya and Durmuş (2008), Yanık (2010), Ata (2011), Ata and Baran (2011).

Today the importance of information technologies and information skills increases, and thus the number of researches on the relation between the information literacy self-efficacy and computer self-efficacy increases day by day. Nonetheless, while there are researches on the self-efficacy aspect that enables the prediction of the phenomenon by the learner, there are no researches to determine whether the aforementioned self-sufficiencies affect the achievement of information literacy. In this study, the research is carried out to determine whether the 
perceptions of self-efficacy in terms of information and computer literacy affect the information literacy achievement of teacher candidates.

\section{Method}

\section{Aim of the Research}

In this study, the relations between the information literacy self-efficacy and computer self-efficacy and the achievement of information literacy are researched. In this context,

- Does the computer self-efficacy affect the information literacy self-efficacy?

- Does the computer self-efficacy affect the achievement of information literacy?

- Does the information literacy self-efficacy affect the achievement of information literacy? Answers to these questions are sought.

\section{Overview of Methodology}

Three different measuring instruments are used in the research. These are the Scale of Information Literacy Self-Efficacy (SILSE), the Scale of Computer Self-Efficacy (SCSE) and the Information Literacy Achievement Test. The Scale of Information Literacy Self-Efficacy is developed by Kurbanoğlu, Akkoyunlu and Umay (2006) and adapted in Turkish by Tuncer (2013). The scale is 7-point likert and the answers and scoring of the scale are as follows: 'Almost Always True', 'Generally True', 'Often True', 'Sometimes True', 'Rarely True', 'Generally not True', 'Almost Never True'. The scoring of the scale is as follows: 'Almost Always True $=7$ ', 'Generally True $=6$ ', 'Sometimes True=4', 'Rarely True=3', 'Generally not True $=2$ ', 'Almost Never True $=1$ '. The cronbach alpha reliability coefficient of the scale is calculated as ,858. As a result of the adaptation effort, the scale is transformed into a 4-factor structure and these 4 factors explain the 58,686 of the total variance.

Another measuring instrument in the research is the Scale of Computer Self-Efficacy developed by Murphy, Coover and Owen (1989). This scale is answered according to the premise of "I Feel Safe" and composed of 29 articles and 5-point likert. The scale is adapted in Turkish by Tuncer (2012) and it is finalized with 17 articles. The answers given to the 5-point likert scale and scoring are as follows 'Strongly Disagree=1', 'Disagree=2', 'Uncertain=3', 'Agree=4' and 'Strongly Agree=5'. The scale is structured to be 4-factor and these 4 factors explain 65,632 of the total variance. The cronbach alpha coefficient of the scale is found to be, 919 .

The Information Achievement Test (IAT), the last data collection instrument of the research, is used by Beile (2005) and adapted by the researches. The achievement test is revised according to the opinions of the experts and after finalizing this test, the item analysis is carried out by applying. When carrying out the item analysis, the distinctiveness and difficulty indexes of the each item within the scope of test are calculated and the results obtained are given in Table 2.

As a result of the item analysis, the reference values given in the Table 1 by Taşpınar (2004:279) for the interpretation of item difficulty and distinctiveness are taken into account. 


\section{Mll Macrothink}

Table 1. The Item Difficulty and Distinctiveness Values and Evaluation of These

\begin{tabular}{ll}
\hline P (Item Difficulty) & Evaluation \\
0,80 and above & Rather easy item \\
$0,65-0,79$ & Easy item \\
$0,35-0,64$ & Mid-level item \\
$0,20-0,34$ & Hard item \\
0,19 and under & Rather hard item \\
$\mathbf{r}$ (Item Distinctiveness) & Evaluation \\
0,40 and above & Very good item \\
$0,30-0,39$ & Good item, but may be improved \\
$0,20-0,29$ & It should generally by corrected \\
$0,00-0,19$ & It may be removed from the test, but should be corrected \\
$(-)$ Negative & It should not be included in the test \\
\hline
\end{tabular}

These reference values and the scope of the test are compared with the item difficulty and item distinctiveness values, and 5 items are removed from the 22-item test. The item difficulty and distinctiveness about the raw form of the achievement test are given in Table 13.

Table 2. The item difficulty and distinctiveness indexes of the achievement test

\begin{tabular}{llllll}
\hline Item & $\mathrm{P}$ & $\mathrm{r}$ & Item & $\mathrm{P}$ & $\mathrm{r}$ \\
\hline 1 & 0,41 & 0,32 & 12 & 0,47 & 0,36 \\
$2^{*}$ & 0,14 & 0,11 & 13 & 0,21 & 0,20 \\
3 & 0,48 & 0,50 & 14 & 0,37 & 0,25 \\
4 & 0,56 & 0,33 & 15 & 0,22 & 0,24 \\
$5^{*}$ & 0,18 & 0,18 & 16 & 0,29 & 0,27 \\
6 & 0,40 & 0,27 & 17 & 0,28 & 0,25 \\
$7^{*}$ & 0,19 & 0,10 & 18 & 0,38 & 0,33 \\
8 & 0,46 & 0,42 & 19 & 0,36 & 0,27 \\
$9^{*}$ & 0,13 & 0,08 & 20 & 0,30 & 0,26 \\
10 & 0,53 & 0,22 & 21 & 0,31 & 0,31 \\
11 & 0,42 & 0,34 & $22 *$ & 0,27 & 0,14 \\
\hline
\end{tabular}

* The items removed from the test, $\mathrm{P}=$ Item Difficulty, $\mathrm{r}=$ Item Distinctiveness

The data collection instruments are applied to 783 teacher candidates receiving education at Faculty of Education in Frrat University. When examined in terms of gender distribution, 422 $(53,9 \%)$ of the teacher candidates participating in the research are female and $361(46,1 \%)$ are male. $126(16,1 \%)$ of the teacher candidates receive education at the department of social sciences teaching, $99(12,6 \%)$ of them at the department of computer and instructional technologies teaching, , $99(12,6 \%)$ of them at the department of elementary mathematics 


\section{Macrothink}

teaching, $137(17,5 \%)$ of them at the department of Turkish teaching, $193(24,6 \%)$ of them at the classroom teaching, $129(16,5 \%)$ of them at the science teaching.

\section{Findings}

The regression analysis is defined with the fact that two or more variables in relation with each other are different in terms of being dependent and independent variables and the process of being explained as a mathematical equity of the relation (Büyüköztürk, 2007). The regression analysis is carried out in order to determine the relation between two or more variables having cause and effect relation and to make predictions about the subject by using this relation. Through analysis, it is determined how the information literacy self-efficacy, computer self-efficacy and the achievement of information literacy affect each other, and the results obtained are given in Figure 1.

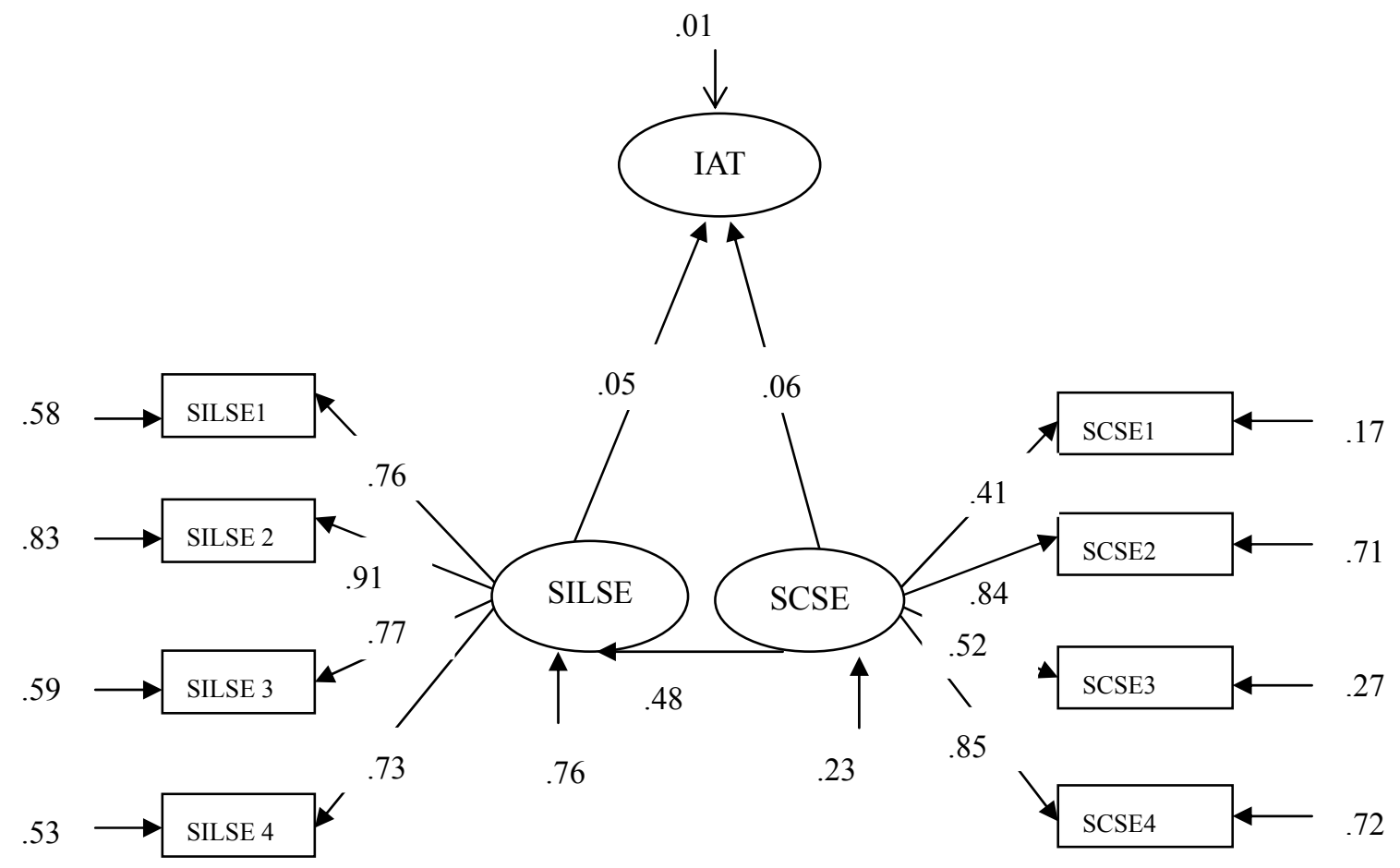

(IAT: The Information Achievement Test, SILSE: Scale of Information Literacy Self-Efficacy, SCSE: The Scale of Computer Self-Efficacy, SILSE $(1,2,3,4)$ and SCSE $(1,2,3,4)$ Factors of Scales)

Figure 1. The SILSE scale, the SCSE scale and The Standardized Regression Analysis

Results of the Achievement Test of Information Literacy

When the standardized regression (beta) coefficients examined, it is observed that the computer self-Efficacy has a positive effect on information literacy self-efficacy $(\beta=, 48$; $\mathrm{p}<.05)$. Nonetheless, it is observed that the information literacy self-efficacy has no 
significant effect on the achievement of information literacy $(\beta=, 06 ; p>.05)$, and likewise the computer self-efficacy has no significant effect on the achievement of information literacy $(\beta=, 05 ; \mathrm{p}>.05)$. This finding can be interpreted as the fact that although the teacher candidates do not think themselves qualified in terms of information literacy self-efficacy and computer self-efficacy, the perception of qualification is not a situation to be discussed in explaining the information literacy achievement. The adjustment index about this model is given in Table 3 .

Table 3. The adjustment index values of the model

\begin{tabular}{llllccccc}
\hline $\mathrm{N}$ & $\mathrm{X}^{2}$ & df & $\mathrm{X}^{2} / \mathrm{df}$ & $\mathrm{CFI}$ & GFI & IFI & RMSEA & SRMR \\
\hline 783 & 138,65 & 25 & 5,54 &, 958 &, 959 &, 958 &, 076 &, 043 \\
\hline
\end{tabular}

When the adjustment index in the table examined, it is observed that $\mathrm{X}^{2} / \mathrm{df}$ value is 5,54 , IFI, CFI and GFI values are close to 1 and RMSEA and SRMR values are close to 0 . When these adjustment indexes are compared with the standards (Stapleton, 1997; Çokluk et al., 2010; Schreiber et al., 2006; Sümer, 2000), it can be said that the model formation is successful.

\section{Conclusion and Discussion}

One of the aspects that we try to clarify with this study is whether the computer self-efficacy affects the information literacy self-Efficacy. As the information and communication technologies are widely used today, it is important to present the relation between these two situations. As a result of the regression analysis, it is observed that the computer self-efficacy has a positive effect on information literacy self-efficacy. Akkoyunlu and Kurbanoğlu (2003) detected a positive relation between the perceptions of information literacy self-efficacy and computer self-efficacy, and observed that the information literacy self-efficacy increased with the perception of computer self-efficacy in parallel with this research. In another research, a mid-level relation is detected between the teacher candidates' perceptions of computer self-efficacy and information literacy skills (Kurbanoğlu \& Akkoyunlu, 2002). When the results obtained are generalized, it is observed that the similar results are obtained when the information literacy self-efficacy is examined in terms of the variables such as internet access, having computer, computer and internet skills. In one of these researches is conducted by Demiralay (2008), it is determined that the teacher candidates' perceptions of information literacy self-efficacy differ according to computer usage experience, level of skill and frequency, computer access conditions, level of internet usage skill and frequency, internet access conditions and usage of different computer applications. In another research, it is precipitated that web-based multi-teaching environment affects the performance of information literacy (Ocak, 2008). Kaya and Durmuş (2008) found a significant relation between the teacher candidates' levels of information literacy and internet usage during research. While Ata (2011) concluded that there is a significant difference among the perceptions of information literacy self-efficacy, computer ownership, internet usage frequency, Web 2.0 technologies and the usage frequencies of these technologies, Ata and Baran (2011) observed that the university students' perceptions of information literacy 
self-efficacy differs according to computer ownership and internet usage frequency. All these research findings present that computer self-efficacy or generally information communication technologies are efficient on information literacy self-efficacy, performance or level. Nonetheless, it is observed that information literacy self-efficacy has no significant effect on the achievement of information literacy, and similarly computer self-efficacy has no significant on the achievement of information literacy. This result should be further researched. While the teacher candidates participating in the research find themselves qualified in terms of computer self-efficacy and information literacy self-efficacy, the fact that this perception of qualification is not efficient on the achievement of information literacy can be interpreted as these persons have no realistic information about the scope or limits of the information literacy. This finding can be evaluated in terms of the system of educating teachers. While the information literacy is classified among the lifelong learning skills, the fact that teacher candidates do not find themselves qualified in terms of this skill may affect their career development negatively. Besides, it is possible that the students will be negatively affected by the choices of these teacher candidates.

\section{References}

Acar, T. (2007). On the concept of self-efficacy. http://www.parantezegitim.net/Bilgi_Bank/Oz_yeterlik_T.Acar_.pdf

Akkoyunlu, B., \& Kurbanoglu, S. (2004). A study on teachers' information literacy self-efficacy beliefs. Hacettepe University Journal of Education, 27, 11-20.

Akkoyunlu, B., \& Kurbanoğlu, S. (2003). A study on teacher candidates' perceived information literacy self-efficacy and perceived computer self-efficacy. Hacettepe University Journal of Education, 24, 1-10.

Albion, P. R. (1999). Self-efficacy beliefs as an indicator of teachers' preparedness for teaching with technology. University of Southern Queensland. http://www.usq.edu.au/users/albion/papers/site99/1345.html

Ata, F. (2011). The investigation of correlation between the undergraduate students' usage of web 2.0 technology and perceptions of information literacy self-efficacy. Unpublished Master's Thesis, Dokuz Eylül University Institude of Educational Sciences, İzmir.

Ata, F. \& Baran, B.(2011). Investigation of undergraduate students' information literacy self-efficacy according to foreign language level, gender, computer ownership and the internet connection duration. $5^{\text {th }}$ International Computer \& Instructional Technologies Symposium, 22-24, Firat University, Elazı̆̆- Turkey.

Beile, P. M. (2005). Development and validation of the information literacy assessment scale for education (ILAS-ED). In American Educational Research Association Annual Meeting, Montreal, Canada.

Bandura, A. (2001). Social cognitive theory: An angetic perspective. Annual Review of Psychology, 54(1), 1-26. http://dx.doi.org/10.1146/annurev.psych.52.1.1

Bandura, A. (1994). Self-efficacy. In V. S. Ramachaudran (Ed.). Encyclopedia of human behavior. New York: Academic Press. 
Bundy, A. (2004). Australian and New Zealand information literacy framework: Principles, standards and practice. (2nd ed.) Adelaide: Australian and New Zealand Institute for Information Literacy. http://www.literacyhub.org/documents/InfoLiteracyFramework.pdf

Büyüköztürk, Ş. (2007). Data analyzing handbook for social sciences. Ankara: Pegem A Publishing.

Compeau, D., \& Higgins, C. A. (1995). Computer self-efficacy: developmental of a measure and initial test. MIS Quarterly, 19(2), 189-211. http://dx.doi.org/10.2307/249688

Çokluk Ö, Şekercioğlu G., \& Büyüköztürk, Ş. (2010). Multivariate statistics for the social sciences: SPSS and LISREL Applied. Ankara: PegemA Publishing.

Demiralay, R. (2008). An evaluation of student teachers' information literacy self-efficacy in point of usage of information and communication technologies. Unpublished Master's Thesis, Gazi University Institute of Educational Sciences, Ankara.

Karsten, R., \& Roth, M. R. (1998). The relationship of computer experience and computer self-efficacy to performance in introductory computer literacy courses. Journal of Research on Technology Education, 31(1), 14-24.

Kaya, S., \& Durmuş, A. (2008). Teacher candidates' level of information literacy and utilizing internet while performing research. 2nd International Computer and Instructional Technologies Symposium (ICITS 2008), 16-18 April, Kuşadası, Turkey.

Korkut, E., \& Akkoyunlu, B. (2008). Foreign language teacher candidates' information and computer literacy perceived self efficacy. Hacettepe University Journal of Education, 34, 178-188.

Kurbanoğlu, S. (2010). Information literacy: A conceptual analysis. Türk Kütüphaneciliği. 24(4), 723-747.

Kurbanoğlu, S., Akkoyunlu, B., \& Umay, A. (2006). Developing the information literacy self-efficacy scale. Journal of Documentation, 62(6), 730-743. http://dx.doi.org/10.1108/00220410610714949

Kurbanoğlu, S., \& Akkoyunlu, B. (2002). Effectiveness of information literacy program applied to initial teacher training students and relation between information literacy skills and perceived computer self-efficacy. Hacettepe University Journal of Education, 22, 98-105.

McClure, Charles R. (1994). Network Literacy: A Role for Libraries. Information Technology and Libraries, 13(2), 115-125.

Murphy, C. A., Coover, D., \& Owen, S. V. (1989). Development and validation of the Computer Self-Efficacy Scale. Educational and Psychological Measurement, 49, 893-899. http://dx.doi.org/10.1177/001316448904900412

Ocak, G. (2008). The effects of web based multimedia environments on the students' information literacy performance. Unpublished Master's Thesis, Hacettepe University Institute of Science, Ankara.

Pajares, F. (1997). Current Directions in Self Efficacy Research In M. Maehr \&P.R. Pintrich 
(Eds.), Advances in Motivation and Achievement, 10, 1-49. Greenwich, CT: JAI Pres.

Polat, C. (2006). An Initiative for university education in the age of information: Information literacy instruction. Atatürk University Journal of the Institute of Turkish Studies, 30, 249-266.

Polat, C. (2005). Development of University Library Based on Information Literacy Programs: Sample of Hacettepe University. Unpublished PhD Thesis, Hacettepe University Institute of Social Sciences, Ankara.

Schreiber J.B, Stage F.K, King J, Nora A., \& Barlow, E.A. (2006). Reporting structural equation modeling and confirmatory factor analysis results: A review. Journal of Educational Research, July/August 99(6).

Schwarzer, R., Bässler, J., Kwiatek, P., \& Schröder, K. (1997). The Assessment of Optimistic Self beliefs: Comparison of The German, Spanish, and Chinese Versions of The General Self efficacy Scale. Applied-Psychology-An-International-Review, 46(1), 69-88. http://dx.doi.org/10.1111/j.1464-0597.1997.tb01096.x

Snyder, C. R., \& Lopez, S. (2002). Handbook of positive psychology, Oxford University Press Us. http://www.voscreen.com/voscreen-next-question/question.jsf

Stapleton, C.D. (1997). Basic concepts in exploratory factor analysis as a tool to evaluate score validity: A right-brained approach. http://ericae.net/ft/tamu/Efa.htm

Sümer N (2000). Structural equation models: basic concepts and applications. Turkish Journal of Psychological, 3(6), 74-79.

Taşpınar, M. (2004). Test and item analysis, Mehmet Gürol(Ed.), Planning and Evaluation in Education (265-285), Ankara: Nobel Publishing

Tuncer, M. (2013). An analysis on the effect of computer self-efficacy over scientific research self-efficacy and information literacy self-efficacy. Educational Research and Reviews, 8(1), $33-40$.

Tuncer, M. (2012). Investigation of effects of computer anxiety and internet attitudes on computer self-efficacy. Journal of Academic Social Science Studies, 5(4), 205-222.

Tuncer, M., \& Tanaş, R.(2011). Evaluation of the computer self-efficacy perceptions of students from faculty of education. Adyaman University Journal of Social Sciences, 4(6), 222-232.

Yanık, C. (2010). The relationship between prospective teachers' computer literacy perception and their attitudes towards internet usage. Hacettepe University Journal of Education, 39, 371-382. 